\title{
Influence of EU policy on agricultural nutrient losses and the state of receiving surface waters in Finland
}

\author{
Petri Ekholm, Kirsti Granlund, Pirkko Kauppila, Sari Mitikka, Jorma Niemi, Katri Rankinen, \\ Antti Räike and Johanna Räsänen \\ Finnish Environment Institute, PO Box 140, FI-00251 Helsinki, Finland, \\ e-mail: petri.ekholm@ymparisto.fi
}

\begin{abstract}
In Finland, the first large-scale efforts to control nutrient loading from agriculture got under way with the introduction of the EU Agri-Environmental Program in 1995. We examined whether these efforts have decreased agricultural nutrient losses and improved the quality of receiving waters. To do so we used monitoring data on fluxes of nutrients and total suspended solids in agricultural catchments in 1990-2004 and on the water quality of agriculturally loaded rivers, lakes and estuaries in 1990-2005. No clear reduction in loading or improvement in water quality was detected. Hydrological fluctuations do not seem to have eclipsed the effects of the measures taken, since there was no systematic pattern in runoff in the period studied. The apparent inefficiency of the measures taken may be due to the large nutrient reserves of the soil, which slowed down nutrient reductions within the period studied. Simultaneous changes in agricultural production (e.g. regional specialisation) and in climate may also have counteracted the effects of agri-environmental measures. The actions to reduce agricultural loading might have been more successful had they focused specifically on the areas and actions that contribute most to the current loading.
\end{abstract}

Key words: Agriculture, eutrophication, nutrients, water quality, runoff, rivers, lakes, estuaries, climate change

\section{Introduction}

In Finland, the first large-scale efforts to reduce nutrient inputs from agriculture were started in 1995, when the country joined the European Union
(EU) and introduced measures to implement its Agri-Environmental Program (EEC 1992). The main objective of the program is to reduce nutrient loads to surface waters, ground waters and the air. Additional objectives are to reduce the risks caused 
by plant protection, to maintain or increase biodiversity, to manage rural landscapes, to preserve humus in soil and to secure good conditions for agriculture. To be eligible for agri-environmental support, farmers had to implement all the basic measures plus one additional measure. They could also apply special voluntary actions. The conditions for support were modified between the first and second program periods (Table 1). In 1995-1999, about $88 \%$ of agricultural land was covered by the Agri-Environmental Program and in 2000-2006 over $90 \%$. During the first period, the sum paid to farmers by the program totalled $€ 259$ million $\mathrm{yr}^{-1}$ and during the latter period about $€ 297$ million $\mathrm{yr}^{-1}$ (Ministry of Agriculture and Forestry 2004, Niemi and Ahlstedt 2005). According to an $a$ priori estimate, adoption of the agri-environmental support scheme would decrease both erosion and nutrient losses into water bodies by some $20-40 \%$ (Valpasvuo-Jaatinen et al. 1997).

The Nitrates Directive (EEC 1991) was transposed to national legislation in 2000 (partially in 1998). The Decree contains provisions on good agricultural practices, storage of manure, spreading and allowable quantities of fertilisers and silage liquor, analysis and recording of $\mathrm{N}$ in fertilisers

Table 1. Main requirements of the Finnish Agri-Environmental Program in its first (1995-1999) and second (2000-2006) periods (Valpasvuo-Jaatinen et al. 1997, Ministry of Agriculture and Forestry 2004).

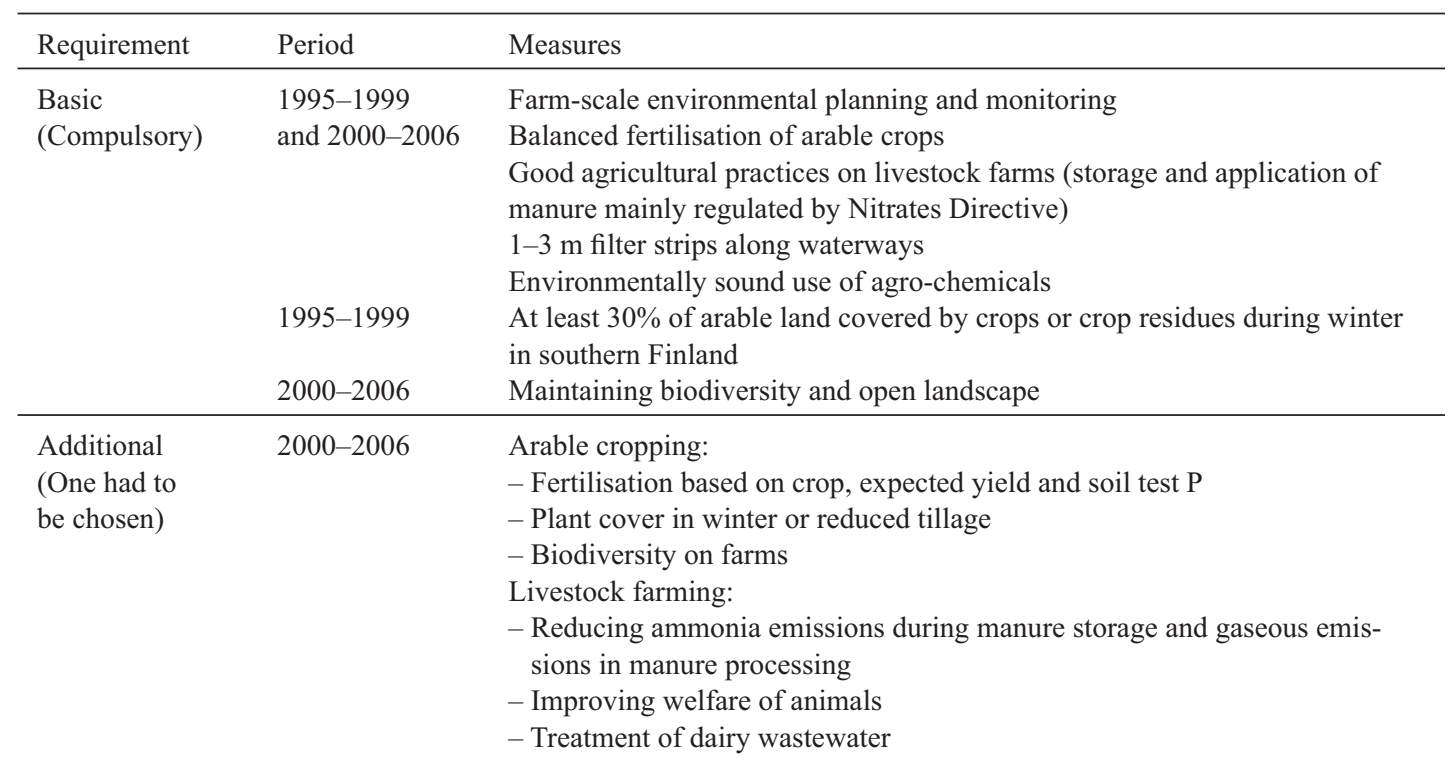

\begin{tabular}{ll}
\hline Special & Riparian zones \\
and 2000-2006 & Wetlands and sedimentation ponds \\
& Organic production \\
& Balanced use of manure \\
& Traditional biotopes \\
& Other measures to enhance biodiversity \\
& Improvement and management of open landscape \\
& Raising local breeds and cultivation of local crops* \\
& Measures to decrease acidity of soil and runoff \\
& Controlled drainage and irrigation, recycling of drainage water \\
& Reducing N losses in arable farming in groundwater areas \\
\hline
\end{tabular}

\footnotetext{
* The latter only in the second period.
} 
Ekholm, P. et al. Nutrient losses and the state of surface waters

and enforcement of the Decree (Mitikka et al. 2005). The Nitrates Directive applies to the whole of Finland without regional or local differentiation. The Water Framework Directive (EC 2000) is a more recent EU-driven pressure on agriculture. It requires the state of surface waters to be sustained and improved by controlling the input of nutrients, the aim being for all surface waters to have a good ecological status by 2015 . This objective calls for assessment of the reference conditions of surface waters. Reference conditions are considered to prevail when disturbances due to human activities are very low or non-existent (EC 2000).

Before 1995, water protection measures within agriculture were implemented through advice and extension with the exception of the short-lived tax on P-fertilizers and obligatory set-aside intended to reduce over-production (Valpasvuo-Jaatinen et al. 1997). In 1995, the national set-aside obligations were replaced by those of the EU, which increased actively cultivated land area from 1.84 million hectares in 1990-1994 to about two million hectares after 1995 (see Fig. 1 for changes in area of set-aside, grasses and cereals). The increase in the cultivated land area may have counteracted the effects of agri-environmental measures to some extent. Moreover, average farm size has increased, agriculture has become more specialised, and the regional division between animal and crop farms has widened since Finland acceded to the EU (Lehtonen and Pyykkönen 2005, Niemi and
Ahlstedt 2005). These tendencies have probably aggravated manure problems, among other things, by increasing the pressure to spread manure in autumn. Moreover, the area of grassland has declined (Fig. 1), increasing the vulnerability of soil to erosion and $\mathrm{N}$ losses.

Recent national policies may also have affected agricultural nutrient losses. For example, the Environmental Protection Act and Decree (issued in 2000) require permits and inspections on large animal farms. In addition, the raising of cattle outdoors in winter and the exercising of animals have become more common, both of which may increase nutrient losses (Uusi-Kämppä 2002, Uusi-Kämppä et al. 2007). Furthermore, the area of direct sowing has increased. Direct sowing effectively curtails erosion but increases losses of dissolved P (Puustinen et al. 2005). On the other hand, fertiliser applications, and consequently soil surface nutrient balances, have been decreasing in Finland since 1990 (Ministry of Agriculture and Forestry 2004).

Recent assessments of agricultural impacts on aquatic systems showed no clear reduction in either nutrient loading or eutrophication (Mitikka and Ekholm 2003, Räike et al. 2003, Granlund et al. 2005, Ekholm and Mitikka 2006). This may partly be explained by the lag period between the measures taken and the desired outcome due to the large nutrient reserves accumulated in the soil (Stålnacke et al. 2003, 2004). The effects of agrienvironmental measures may be further obscured

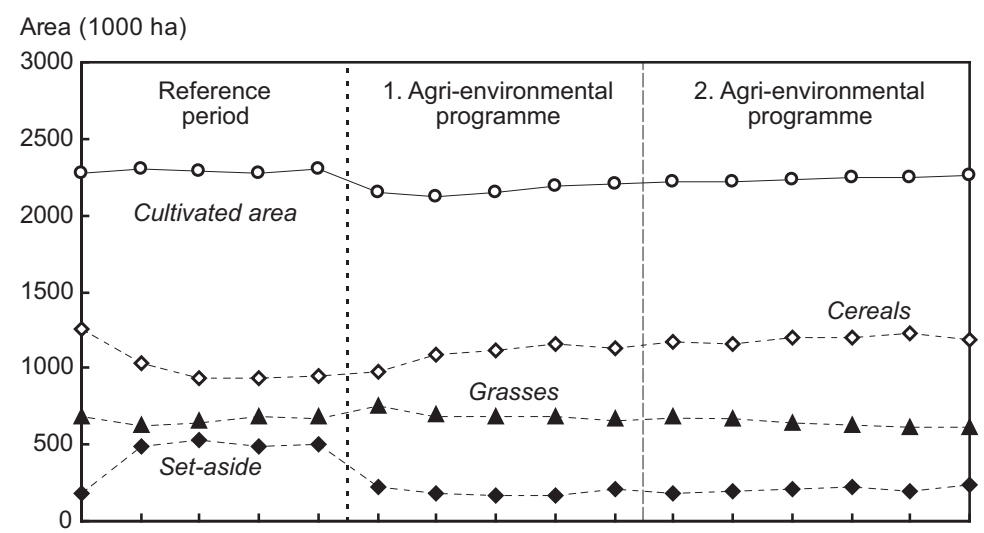

1990199119921993199419951996199719981999200020012002200320042005
Fig. 1. Area of agricultural land in Finland in 1990-2005. Data from the Information Centre of the Ministry of Agriculture and Forestry. 
by variations in hydrology, especially outside the growing season, when fields lack vegetation to take up nutrients or prevent erosion. When a mild and rainy winter follows a rainy autumn, concentrations of total suspended solids (TSS) and particulate $\mathrm{P}(\mathrm{PP})$ in runoff may be double what they are when a cold winter follows a dry autumn (Puustinen et al. 2007). Observations from exceptionally mild winters indicate that $\mathrm{N}$ losses, too, can increase (Kallio et al. 1997). Wivstad et al. (2005) reported mineralisation of organic matter in agricultural soils outside the growing season, suggesting that the leaching of soluble nutrients depends on both runoff and soil processes. Winter runoff increased in southern and central Finland during the $20^{\text {th }}$ century, as did annual discharges in the south and west to some extent. Precipitation increased in southern and central Finland, but there were no signs of long-term trends in annual evaporation (Hyvärinen 2003). There has been a clear rise in spring (March-May) air temperatures during the last 150 years (Tuomenvirta 2004), and the winters since 1988 have been milder than average (Drebs et al. 2002).

Because of the variations in nutrient losses, runoff, weather and farming practices, the differences produced by agricultural practices are hard to distinguish from those caused by other factors (Vagstad et al. 2004, Kronvang et al. 2005). In Norway, the concentration of TSS and total P (TP) declined due to erosion control and improved management of animal manure (Bechmann and Stålnacke 2005). In Sweden, downward trends in dissolved reactive $\mathrm{P}$ (DRP) and in $\mathrm{NO}_{3}-\mathrm{N}$ from small agricultural catchments may have been due to a reduction in manure application (especially in autumn) and a change in crop distribution (Kyllmar et al. 2006). On the other hand, in Swedish agricultural rivers, the recent decreasing trends observed in reactive $\mathrm{N}$ may have been related to an increased area of catch crops and set-aside, a reduced area of autumn tillage and more efficient production (Ulén and Fölster 2007). In Denmark, a reduction in agricultural nutrient balances ( $41 \%$ for $\mathrm{N}$ and $42 \%$ for $\mathrm{P}$ ), for example, resulted in a decrease in total $\mathrm{N}(\mathrm{TN})$ in agricultural streams, but no significant trends were found for TP (Kronvang et al. 2005).
None of the Finnish studies, except that of Granlund et al. (2005), which covered only the first programme period (1995-1999), concentrated explicitly on the effect of agri-environmental measures required by the EU. Since many of these measures have now been in operation for more than ten years, their effects should be visible in the environment. We sought to look for changes in agricultural nutrient loading and in the state of agriculturally impacted surface waters with the aid of monitoring data collected by the environmental authorities on small-, medium- and meso-scale agricultural catchments, rivers, lakes and coastal waters. Further, we investigated the reference state of agriculturally loaded lakes on the basis of sediment diatom assemblages. Our study is the first effort to compile all relevant monitoring data from agriculturally loaded waters in Finland. Since hydrological changes can mask the effects of water protection measures, special emphasis was paid to analysing trends in runoff.

\section{Material and methods}

\section{Study sites}

The trend in nutrient fluxes $\left(\mathrm{kg} \mathrm{km}^{-2} \mathrm{yr}^{-1}\right)$ was analysed on the basis of water quality and flow measurements in two small-scale catchments (Savijoki, $15.4 \mathrm{~km}^{2}$, of which $39 \%$ was cultivated; Löytäneenoja, $5.64 \mathrm{~km}^{2}, 68 \%$ cultivated), one medium-scale catchment (Yläneenjoki, 233 km², 27\% cultivated) and 13 meso-scale rivers discharging into the Baltic Sea (listed in Fig. 5, 487-4923 km², proportions of fields and lakes in the catchment $21-44 \%$ and $0.3-13 \%$, respectively). All these sites were located in southern and western Finland (Fig. 2).

Runoff from the two small catchments was sampled manually (ca. $15 \mathrm{yr}^{-1}$ ) and automatically [ca. 30-50 $\mathrm{yr}^{-1}$ flow-weighted, see Vuorenmaa et al. (2002)]. In the Yläneenjoki catchment, the sampling frequency was $12-70 \mathrm{yr}^{-1}$. In these three catchments, the dominant production sector was cereal cultivation, the present proportion of animal farms being 
Ekholm, P. et al. Nutrient losses and the state of surface waters

approximately 20\% (Mattila et al. 2007). As there are no lakes in the catchments and artificial drainage is widely used on the fields, the residence time of water is short, and nutrient retention in the surface waters is therefore probably low. The 13 meso-scale rivers were typically sampled $12-20 \mathrm{yr}^{-1}$.

Annual loads of TP, DRP, TN, $\mathrm{NO}_{\mathrm{x}}-\mathrm{N}$ and $\mathrm{NH}_{-}$ -N for the two small-scale catchments were provided by Vuorenmaa et al. (2002) in 1990-1997. These data were complemented with calculations of annual loads for nutrients for 1998-2004, and for TSS in the entire study period. In the Yläneenjoki catchment and the 13 meso-scale rivers, annual losses were calculated for each variable. The load estimates presented below represent the sum of all non-point losses, point-source loading

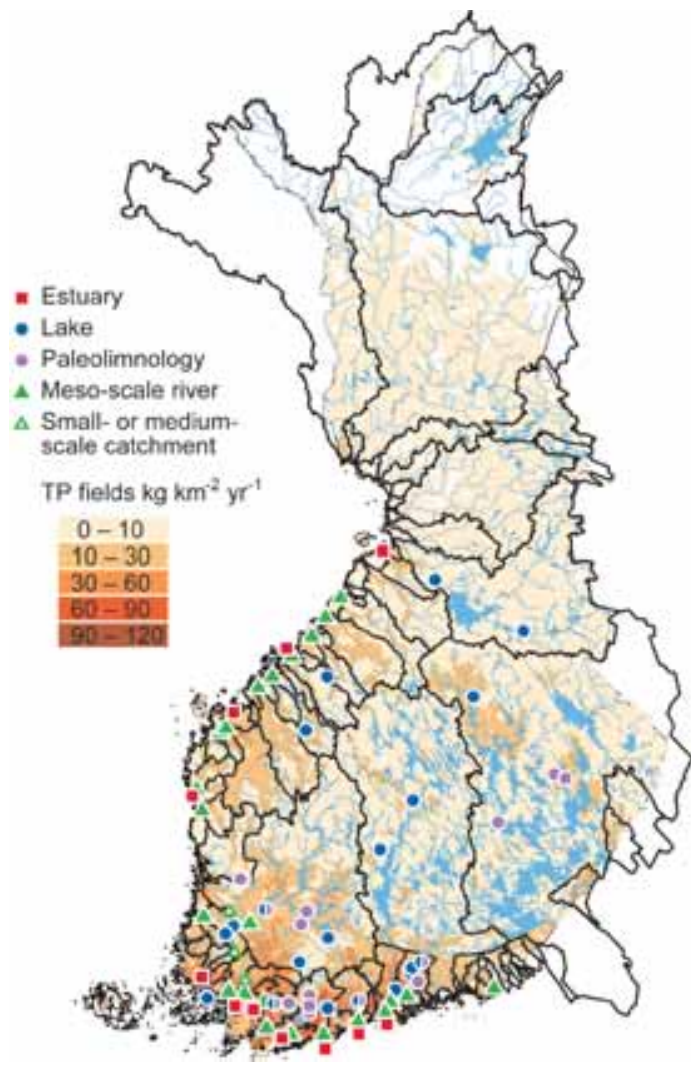

Fig. 2. Study sites and an estimate of agricultural loading in Finland based on the assessment system [VEPS, Tattari and Linjama (2004)] of the Finnish Environment Institute. The main river catchment areas are marked with lines. and natural background. Point-source loading was low or nonexistent, except in the River Porvoonjoki, where it accounted for approximately one quarter of the TN flux. The contribution of natural background was also low, as were impacts of forestry practices. Thus, at all sites, agriculture was the main source of nutrients.

As well as changes in fluxes, trends in water quality were examined in 20 rivers, 20 lakes and 12 estuaries, all impacted by agriculture (Fig. 2). The river data set consisted of ten of the above rivers (excluding the Siuntionjoki, Loimijoki and Närpiönjoki) plus 10 other rivers discharging into the Baltic Sea. Their catchments ranged from 357 to $4923 \mathrm{~km}^{2}$ and the field and lake proportions of the catchments from $9.4 \%$ to $44 \%$ and from $0.2 \%$ to $13 \%$, respectively. All sites received nutrients from other sources besides agriculture. For details of the rivers, see Mitikka et al. (2005).

The 20 lakes studied are listed in Table 2 and have been described in detail by Ekholm and Mitikka (2006). Their size ranged from 0.4 to $155 \mathrm{~km}^{2}$ and their maximum depth from 1.7 to $68 \mathrm{~m}$. The majority did not undergo thermal stratification in summer. Of their catchment area, $6 \%$ to $41 \%$ was agricultural land, the remainder consisting of forest and peatland. At all sites, agriculture was the main anthropogenic source of nutrients. Some of the lakes were subject to in-lake restoration. The lakes were sampled approximately 1-9 times a year.

Because algal blooms are a serious problem, particularly in small Finnish lakes, temporal changes in the intensity and frequency of algal blooms during 1998-2005 were also evaluated. The data were based on the Finnish monitoring network of algal blooms, which comprises 145 lake sites situated throughout the country and varying in size, depth and trophy. Local environmental authorities have visually estimated algal abundances weekly in summer since 1998 (Lepistö et al. 1998).

The 12 estuaries (15 sites) studied (listed in Table 3, except for Mustijoki and Närpiönjoki) varied from well-mixed, stratified estuaries and relatively enclosed systems to winding, island-rich systems and relatively simple pocket estuaries. They were small $\left(2-101 \mathrm{~km}^{2}\right)$ and shallow (mean 
Vol. 16 (2007): 282-300

Table 2. Water quality trends (Kendall's tau-b) of 20 agriculturally loaded lakes in 1990-2005. Late summer upper water layer. Empty space $=$ no data.

\begin{tabular}{lccccccc}
\hline Lake & $\begin{array}{c}\text { Total } \\
\mathrm{N}\end{array}$ & $\mathrm{NH}_{4} \mathrm{~N}$ & $\begin{array}{c}\mathrm{NO}_{\mathrm{x}} \mathrm{-N} \\
\text { Ahmasjärvi }\end{array}$ & $\begin{array}{c}\text { Total } \\
\mathrm{P}\end{array}$ & $\begin{array}{c}a \text {-chloro- } \\
\text { phyll }\end{array}$ & $\begin{array}{c}\text { Secchi } \\
\text { depth }\end{array}$ & Turbidity \\
Ahveninen & & & & & & & \\
Enäjärvi & -0.05 & & 0.18 & 0.30 & 0.03 & -0.33 & -0.11 \\
Juoksjärvi & -0.25 & -0.25 & $-0.56^{*}$ & $-0.44^{*}$ & -0.14 & $0.66^{* *}$ & -0.34 \\
Karhijärvi & 0.21 & & 0.17 & 0.26 & $0.39^{*}$ & $-0.53^{* *}$ & 0.07 \\
Kirkkojärvi & -0.42 & $-0.48^{*}$ & 0.10 & 0.05 & $-0.53^{*}$ & 0.22 & -0.05 \\
Kirmanjärvi & -0.38 & $-0.43^{*}$ & -0.44 & $-0.41^{*}$ & -0.23 & 0.39 & \\
Köyliönjärvi & 0.02 & -0.26 & -0.27 & -0.21 & -0.10 & 0.01 & \\
Lappajärvi & 0.16 & $-0.46^{*}$ & -0.13 & 0.34 & -0.30 & -0.14 & $0.45^{*}$ \\
Lehijärvi & $0.43^{*}$ & -0.18 & 0.36 & 0.04 & -0.02 & -0.09 & 0.16 \\
Pusulanjärvi & 0.10 & -0.31 & -0.19 & 0.11 & 0.11 & -0.33 & 0.11 \\
Pyhäjärvi (Säkylä) & $0.46^{*}$ & -0.29 & 0.12 & $0.43 *$ & 0.17 & -0.16 & $0.45^{*}$ \\
Pyhäjärvi (Tammela) & -0.01 & -0.14 & 0.07 & -0.09 & 0.33 & -0.10 & 0.30 \\
Pyhäjärvi (Artjärvi) & 0.04 & & -0.39 & 0.02 & 0.37 & $-0.52^{*}$ & 0.20 \\
Sotkamojärvi & -0.24 & -0.01 & -0.20 & 0.00 & 0.16 & -0.04 & 0.16 \\
Sääskjärvi & $0.72^{* *}$ & -0.11 & 0.05 & $0.57 *$ & 0.38 & -0.42 & $0.72^{* *}$ \\
Tiiläänjärvi & 0.16 & & & -0.07 & 0.28 & -0.22 & 0.11 \\
Ullavanjärvi & -0.11 & & & 0.29 & & & \\
Villikkalanjärvi & $0.50^{*}$ & -0.20 & 0.31 & 0.36 & 0.29 & -0.53 & \\
Ylisjärvi & 0.25 & 0.23 & -0.05 & 0.18 & 0.04 & -0.37 & 0.40 \\
\hline & 0.08 & 0.06 & -0.39 & 0.22 & 0.24 & 0.07 & $0.43^{*}$ \\
\hline
\end{tabular}

$*=p<0.05, * *=p<0.01, * * *=p<0.001$

depth 3.8-18 m), with a salinity below 6 psu and a residence time from 0.04 to $5.62 \mathrm{yr}$. All the estuaries were non-tidal, the northern Baltic Sea having a weak tide of less than $3 \mathrm{~cm}$ on average (Myrberg et al. 2006). The proportions of fields in the catchments ranged from $10 \%$ to $43 \%$. Three of the estuaries received direct point source loading (Porvoonjoki, Pohjanpitäjänlahti, Halikonlahti). The estuaries have been discussed in greater detail by Meeuwig et al. (2000) and Kauppila et al. (2003). The estuaries were sampled approximately 24 times a year.

Finally, for paleolimnological studies, sediment samples were taken from 15 agricultural lakes (fields in the catchment $11 \%-34 \%$ ) in 2003 and diatoms were analysed from the top $(0-2 \mathrm{~cm})$ and bottom $(30-90 \mathrm{~cm})$ sediments [sampling and analysis described by Räsänen et al. (2006)]. Surface sediments represent present conditions and deeper sediments background conditions (Cumming et al. 1992, Miettinen et al. 2005). Bottom samples were taken from the homogenous sediment below any visible signs of human-disturbance, such as changes in sediment colour or composition. The lakes have been subjected to anthropogenic impacts for a long time and therefore the background conditions do not necessarily represent the pristine state, but rather the reference conditions described in the Water Framework Directive (EC 2000).

In summary, data were analysed from 72 agriculturally impacted sites (excluding the algal bloom lakes). Based on an estimate of the assessment system [VEPS, Tattari and Linjama (2004)] of the Finnish Environment Institute, the sites cover the areas with high agricultural loading of $\mathrm{P}$ (Fig. 2) rather well. The monitoring programmes from which the data were derived have been described by Niemi (2006). 


\section{Ekholm, P. et al. Nutrient losses and the state of surface waters}

Table 3. Water quality trends (Kendall's tau-b) in agriculturally loaded estuaries in summer (16 Jul-15 Sep) and winter (Jan-Apr) in 1990-2005. Upper water layer, except for oxygen saturation, which is from near-bottom water. Empty space $=$ no data.

\begin{tabular}{|c|c|c|c|c|c|c|c|c|}
\hline $\begin{array}{l}\text { Estuary/ } \\
\text { Site }\end{array}$ & $\begin{array}{c}\text { Total } \\
\mathrm{N}\end{array}$ & $\mathrm{NH}_{4}-\mathrm{N}$ & $\mathrm{NO}_{\mathrm{x}}-\mathrm{N}$ & $\begin{array}{c}\text { Total } \\
\mathrm{P}\end{array}$ & $\begin{array}{c}a \text {-chloro- } \\
\text { phyll }\end{array}$ & $\begin{array}{l}\text { Secchi } \\
\text { Depth }\end{array}$ & Turbidity & $\begin{array}{c}\mathrm{O}_{2} \\
\text { saturation }\end{array}$ \\
\hline \multicolumn{9}{|l|}{ Summer } \\
\hline Porvoonjoki & -0.05 & -0.23 & -0.33 & 0.08 & -0.33 & 0.06 & 0.30 & -0.26 \\
\hline Vanhankaupunginlahti & -0.08 & 0.13 & -0.12 & -0.10 & -0.20 & -0.05 & 0.33 & 0.05 \\
\hline Pikkalanlahti & 0.35 & -0.03 & -0.32 & 0.08 & 0.34 & -0.35 & & 0.13 \\
\hline \multicolumn{9}{|l|}{ Pohjanpitäjänlahti } \\
\hline - Inner & -0.15 & -0.08 & & -0.25 & 0.07 & -0.09 & -0.35 & -0.17 \\
\hline - Outer & 0.17 & -0.27 & 0.05 & -0.17 & 0.17 & -0.35 & -0.14 & $-0.41 *$ \\
\hline \multicolumn{9}{|l|}{ Halikonlahti } \\
\hline - Inner & -0.06 & 0.18 & 0.04 & 0.15 & -0.11 & -0.18 & 0.15 & -0.29 \\
\hline - Outer & 0.45 & -0.32 & & 0.15 & $0.55^{*}$ & 0.00 & -0.06 & 0.21 \\
\hline \multicolumn{9}{|l|}{ Paimionlahti } \\
\hline - Inner & 0.23 & & & 0.13 & 0.18 & -0.19 & 0.29 & -0.20 \\
\hline - Outer & $0.54 * *$ & -0.36 & 0.14 & $0.39 *$ & 0.24 & $-0.41 *$ & $0.47^{*}$ & -0.11 \\
\hline Mynälahti & 0.27 & -0.03 & -0.14 & 0.17 & 0.10 & 0.13 & 0.05 & 0.17 \\
\hline Kyrönjoki & -0.22 & & & -0.2 & & & & \\
\hline \multicolumn{9}{|l|}{ Perhonjoki } \\
\hline - Inner & -0.09 & -0.01 & -0.03 & -0.30 & $-0.43 *$ & 0.33 & $-0.44 *$ & 0.09 \\
\hline - Outer & -0.19 & -0.18 & 0.09 & -0.24 & $-0.53 * *$ & $0.64 * * *$ & $-0.62 * *$ & 0.05 \\
\hline Liminganlahti & $0.51 *$ & 0.24 & 0.16 & -0.13 & 0.16 & & -0.36 & 0.27 \\
\hline \multicolumn{9}{|l|}{ Winter } \\
\hline Vanhankaupunginlahti & 0.2 & 0.16 & 0.13 & 0.11 & & 0.22 & -0.16 & -0.38 \\
\hline Pikkalanlahti & -0.04 & & & 0.29 & & -0.32 & & 0.27 \\
\hline \multicolumn{9}{|l|}{ Pohjanpitäjänlahti } \\
\hline - Inner & -0.12 & 0.10 & & -0.26 & & 0.24 & -0.30 & -0.12 \\
\hline - Outer & $-0.46^{*}$ & -0.35 & $-0.54 * *$ & -0.23 & & 0.31 & $-0.49 *$ & -0.11 \\
\hline \multicolumn{9}{|l|}{ Halikonlahti } \\
\hline - Inner & -0.14 & -0.17 & 0.10 & -0.36 & & 0.33 & -0.12 & -0.07 \\
\hline - Outer & 0.20 & 0.13 & 0.11 & -0.09 & & 0.28 & -0.27 & 0.02 \\
\hline \multicolumn{9}{|l|}{ Paimionlahti } \\
\hline - Inner & -0.28 & -0.29 & & $-0.39 *$ & & -0.32 & -0.22 & 0.31 \\
\hline - Outer & 0.05 & -0.01 & 0.01 & 0.02 & & 0.07 & -0.19 & 0.00 \\
\hline Mynälahti & 0.33 & -0.05 & 0.29 & 0.04 & & 0 & -0.02 & -0.01 \\
\hline Kyrönjoki & -0.22 & & & -0.20 & & & -0.45 & \\
\hline \multicolumn{9}{|l|}{ Perhonjoki } \\
\hline - Inner & -0.14 & $-0.40^{*}$ & & $-0.55^{* *}$ & & -0.13 & -0.27 & 0.08 \\
\hline - Outer & 0.32 & 0.30 & $0.60 * *$ & 0.10 & & & $0.44 *$ & 0.23 \\
\hline Liminganlahti & 0.2 & 0.24 & & 0.24 & & & & -0.04 \\
\hline
\end{tabular}

$*=p<0.05, * *=p<0.01, * * *=p<0.001$

\section{Analyses of water quality}

The level of chlorophyll $a$ (a-chl) was determined spectrophotometrically from an acetone (since 1994 from an ethanol) extract of the matter retained by fibreglass filters. Oxygen was analysed by Winkler's method. Total $\mathrm{N}$ determination was initiated by digestion with peroxodisulphate, followed by reduction of $\mathrm{NO}_{3}$ with a $\mathrm{Cd}$ amalgam and determination of $\mathrm{NO}_{2}$ by the azo colour method. $\mathrm{NO}_{3}-\mathrm{N}$ and $\mathrm{NO}_{2}-\mathrm{N}$ were analysed using the same basic procedure as described above, and $\mathrm{NH}_{4}-\mathrm{N}$ was analysed by the indophenol blue method. The sum of $\mathrm{NO}_{3}-\mathrm{N}$ and $\mathrm{NO}_{2}-\mathrm{N}\left(\mathrm{NO}_{\mathrm{x}}-\mathrm{N}\right.$; the 
concentration of $\mathrm{NO}_{3}-\mathrm{N}$ was used if $\mathrm{NO}_{2}-\mathrm{N}$ was lacking) is given below. Phosphorus analysis was performed by the molybdenum blue method with ascorbic acid as a reductant (Murphy and Riley 1962). For determination of TP, the sample was digested with potassium peroxodisulphate before the $\mathrm{P}$ analysis. Total dissolved $\mathrm{P}$ (TDP) and DRP were analysed on a filtered sample (Whatman/ Nuclepore polycarbonate, pore size $0.4 \mu \mathrm{m}$ ); in the analysis of TDP, the sample was digested before staining, whereas DRP was determined without digestion. Reactive P (RP) was analysed similarly to DRP, but on an unfiltered sample. Dissolved inorganic P (DIP) was assumed to be equal to DRP and dissolved inorganic $\mathrm{N}$ to the sum of $\mathrm{NO}_{\mathrm{x}}-\mathrm{N}$ and $\mathrm{NH}_{4}-\mathrm{N}$. TSS were analysed gravimetrically by filtering samples with Nuclepore filters. Secchi depth was determined with a white disc and turbidity nephelometrically. Faecal enterococci were enumerated by a membrane filter technique and m-Enterococcus agar at 35 or $37^{\circ} \mathrm{C}$ for two days.

\section{Data analysis}

Water quality and daily water flow data were extracted from the data bases of the Finnish Environment Institute. Annual losses of nutrients and TSS from the agricultural catchments were estimated using the period method (Rekolainen et al. 1991). To level off the effect of annual variation in the observed fluxes, 5-year mean fluxes were examined for the following three periods: 1990-1994 (the reference period when the agri-environmental programme was not yet applied), 1995-1999 (the first period of the programme) and 2000-2004 (the second period of the programme).

The trends in the analysed concentrations in the runoff from agricultural catchments were studied using the non-parametric partial MannKendall test of Libiseller and Grimvall (2002), which accounts for seasonality and adjusts the concentrations with water flow (flow being a covariate). Owing to the scarcity of data, only two seasons were included (Jan-Jun and Jul-Dec) in the trend analysis for the two small catchments; in larger catchments, monthly mean values were used. DRP was analysed in small and mediumsized catchments and TDP in the meso-scale catchments.

The water quality of the 20 rivers was studied by calculating the annual and seasonal (summer, 15 Jul-30 Sep; winter, Jan-Apr) median concentrations for the three periods. All available observations from all depths were used. The seasonal medians within the periods did not differ much from each other, though the winter medians tended to be somewhat higher than the summer ones, particularly for $\mathrm{NH}_{4}-\mathrm{N}$. Only annual values are presented below.

Water quality trends in lakes and estuaries (1990-2005) were analysed using Kendall's tau-b. In lakes, the trend analysis was carried out for the 0-2-m layer and the near-bottom water layer for summer (16 Jul-15 Sep) and winter (Jan- Apr). In estuaries, the analysis was performed for the inner and outer sampling sites of each estuary on samples taken at $1 \mathrm{~m}$ (a-chl from 0 to $2-4 \mathrm{~m}$ ) and near the bottom. In estuarine data, July to September represented summer, and February and March winter.

Algal bloom sites were divided by expert judgement into agriculturally impacted sites $(n=57)$ and other sites $(n=88)$. Algal blooms were classified as four abundance classes $(0=$ not visible, $1=$ present, $2=$ abundant, $3=$ very abundant). A bloom index was calculated as the relative number of observations weighted by the abundance of the algal bloom. The index was first calculated for every year, and then averaged over the years for each site. The maximum value of the bloom index is 3 , which was obtained when all (non-missing) weekly observations were classified as very abundant. To characterize the lake population, the water chemistry $(0-2 \mathrm{~m})$ at sampling sites nearest each algal bloom observation site in July-August 1998-2005 was examined. For each sampling site and water quality variable, first the annual means and then the period medians were calculated.

Finally, the long-term changes in 15 agricultural lakes were analysed by the transfer func- 
tion of Kauppila et al. (2002), which describes the relationships between fossil sediment diatom assemblages and the concentration of TP in water (Stroemer and Smol 2000, Battarbee et al. 2001, Smol 2002, Miettinen 2003). The calibration data set for the model consisted of 61 southern Finnish lakes with an autumnal epilimnetic TP range of 3-89 $\mu \mathrm{g}^{-1}$. The transfer function was generated with the simple weighted averaging regression (Ter Braak and van Dam 1989).

Meriläinen et al. (1983) listed the typical diatom species found in productive and disturbed Finnish lakes surrounded by fields, and Miettinen (2003) presented the indicator species for agricultural areas. These species are Aulacoseira ambigua, A. granulata, A. perglabra, A. tenella, A. subarctica, Cyclostephanos dubius, Stephanodiscus hantzschii, S. minutulus, Cyclotella stelligera, C.pseudostelligera, Asterionella formosa, Fragilaria brevistriata, F. construens, F. lapponica, F. pinnata and Navicula pupula. Changes in amounts of these diatoms were also examined here.

\section{Hydrology}

Annual and seasonal trends (May-Sep; Oct-Dec; Jan-Apr) during 1990-2004 in daily discharge $\left(\mathrm{m}^{3}\right.$ $\mathrm{s}^{-1}$ ) and monthly cumulative runoff $(\mathrm{mm})$ in all 23 rivers described above were analysed by linear regression analysis. Generalised Least Squares estimation with an ARMA-type model was applied to include autocorrelation of residuals (Brockwell and Davis 2002).

In addition, changes in extreme values (floods) between the agri-environmental programme period (1995-2004) and the preceding 10-year period (1985-1994) were examined. The magnitude of an extreme event is inversely related to its occurrence such that severe floods occur less frequently than moderate ones. Seasonality of floods was studied by means of frequency analysis (Chow et al. 1988). The annual maximum discharge in winter, summer and autumn was selected from recorded discharge time series. Extreme values were assumed to follow Gumbel's distribution. An increase (decrease) in the extreme value was assumed when the value in the latter period exceeded (went below) the $95 \%$ confidence interval of the extreme value of the first period.

North Atlantic Oscillation (NAO) is a recurrent pattern of atmospheric circulation variability and has been connected to hydrology in several studies (e.g. Yoo and D'Odorico 2002, Kalayci and Kahya 2006). It refers to a redistribution of atmospheric mass between the Arctic and the subtropical Atlantic. Positive values of the winter mean index indicate stronger-than-average westerly flows over the middle latitudes. An enhanced westerly flow across the North Atlantic in winter moves warm and moist maritime air over northern Europe, causing winters in Finland to be mild and rainy. The NAO index was compared with annual discharge in rivers and streams from which data were available from at least the 1960s. Data on annual discharges at each site were divided into two subsets according to the NAO index, i.e. the years with a negative NAO index and those with a positive NAO index. The relationship between the mean discharge and the NAO index was studied using Kendall's correlation.

\section{Results}

\section{Trends in discharge}

No annual or seasonal trend was observed in daily discharge or monthly cumulative runoff in any of the catchments (data not shown). Moreover, no trend was found in the winter NAO index, which was positive in 12 out of 16 years during 1990-2005 (see Fig. 3). The NAO index correlated with the annual mean discharge in three (Aurajoki, Loimijoki, Kalajoki) of the 13 rivers with long discharge data (data not shown).

There were no changes in the 10 -year design flood (the maximum discharge taking place once every ten years) of the rivers in southern Finland (Virojoki, Porvoonjoki, Mustijoki, Vantaanjoki, Karjaanjoki, Kiskonjoki, Uskelanjoki) between 
Fig. 3. NAO index and annual runoff in the River Aurajoki in 1985-2005.

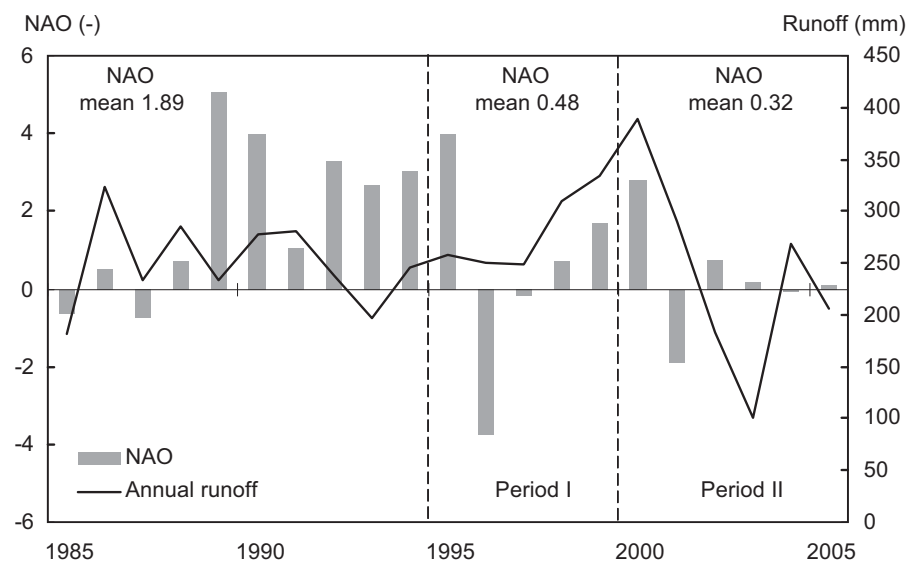

Runoff (mm)

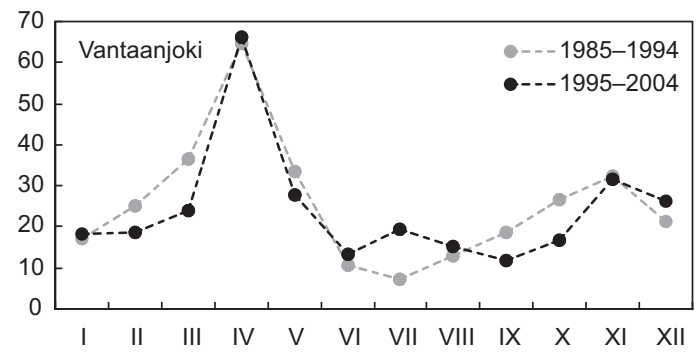

Runoff (mm)

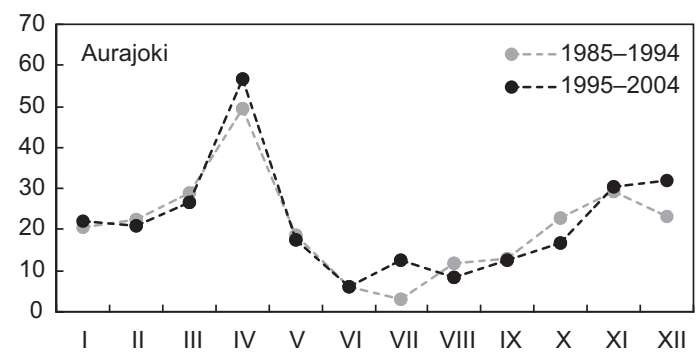

Runoff (mm)

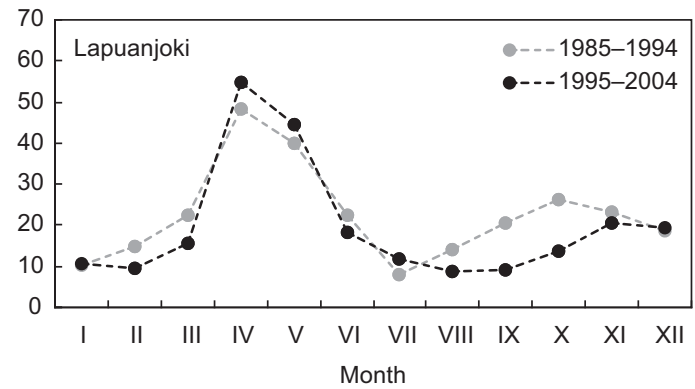

Fig. 4. Mean monthly discharge in the Rivers Vantaanjoki, Aurajoki and Lapuanjoki in 1985-1994 and 1995-2004.
1985-1994 and 1995-2004. However, in the rivers of south-western Finland (Paimionjoki, Aurajoki, Yläneenjoki, Loimijoki) the summertime design flood was lower during 1995-2004 than during 1985-1994 $(p<0.05)$. This pattern also applied to the Perhonjoki, a river in western Finland. By contrast, in several rivers (Kyrönjoki, Lapuanjoki, Ähtävänjoki, Kalajoki) in an area with intensive animal production in western Finland, the winter design flood tended to be higher in 1995-2004 than in the preceding period. A comparison of monthly mean discharges in western Finland (Fig. 4) showed that the spring flow peak was more pronounced and the autumn discharge lower during 1995-2004. In the other two regions, no clear pattern emerged.

\section{Trends in agricultural nutrient fluxes}

Figure 5 shows the mean runoff and the mean fluxes of nutrients and TSS from the 16 agricultural catchments in the reference period (1990-1994) and in the two periods of the agri-environmental programme (1995-1999 and 2000-2004). Although there were no statistically significant trends in daily, seasonal or annual water runoff, the five-year mean runoff tended to decrease from the reference period to the second stage of the agri-environmental programme in many catchments. To account for this pattern, we here examine the trends in flow-adjusted concentrations. 
Ekholm, P. et al. Nutrient losses and the state of surface waters
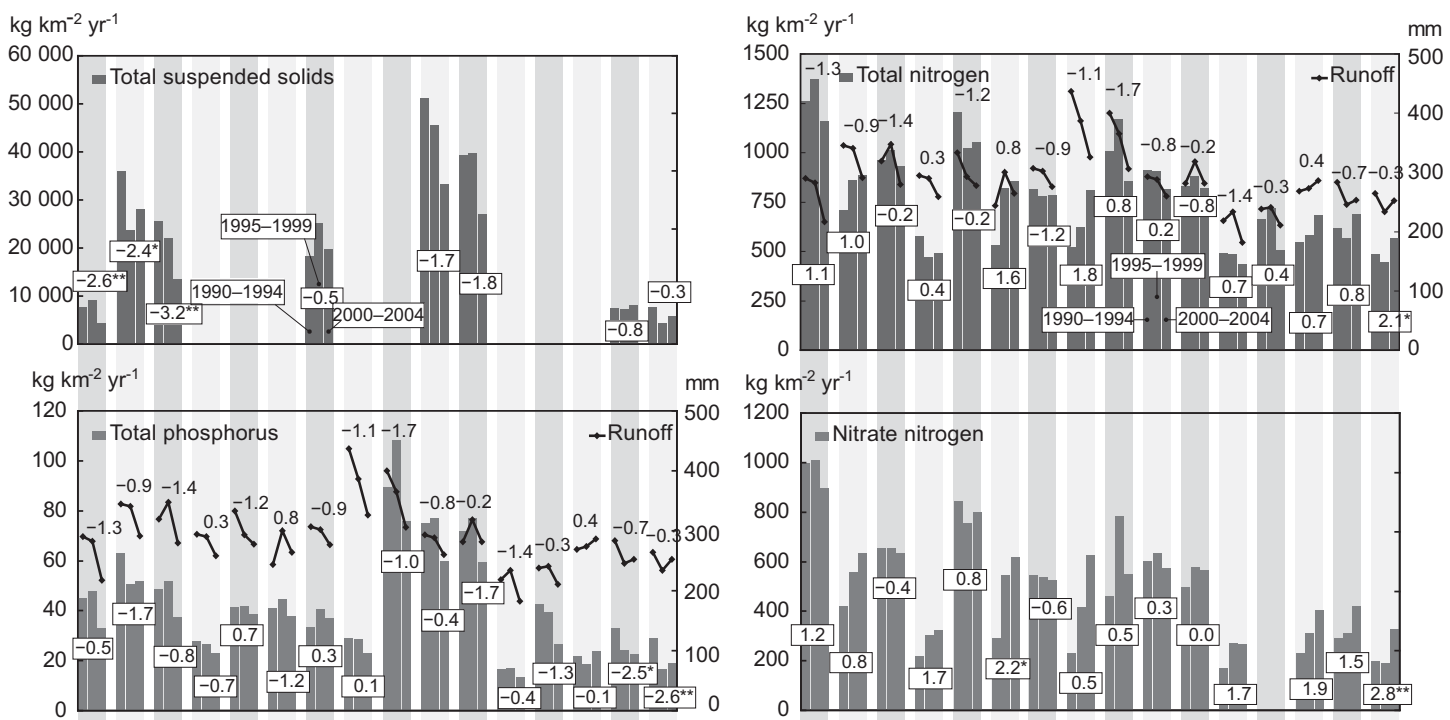

$\mathrm{kg} \mathrm{km}^{-2} \mathrm{yr}^{-1}$
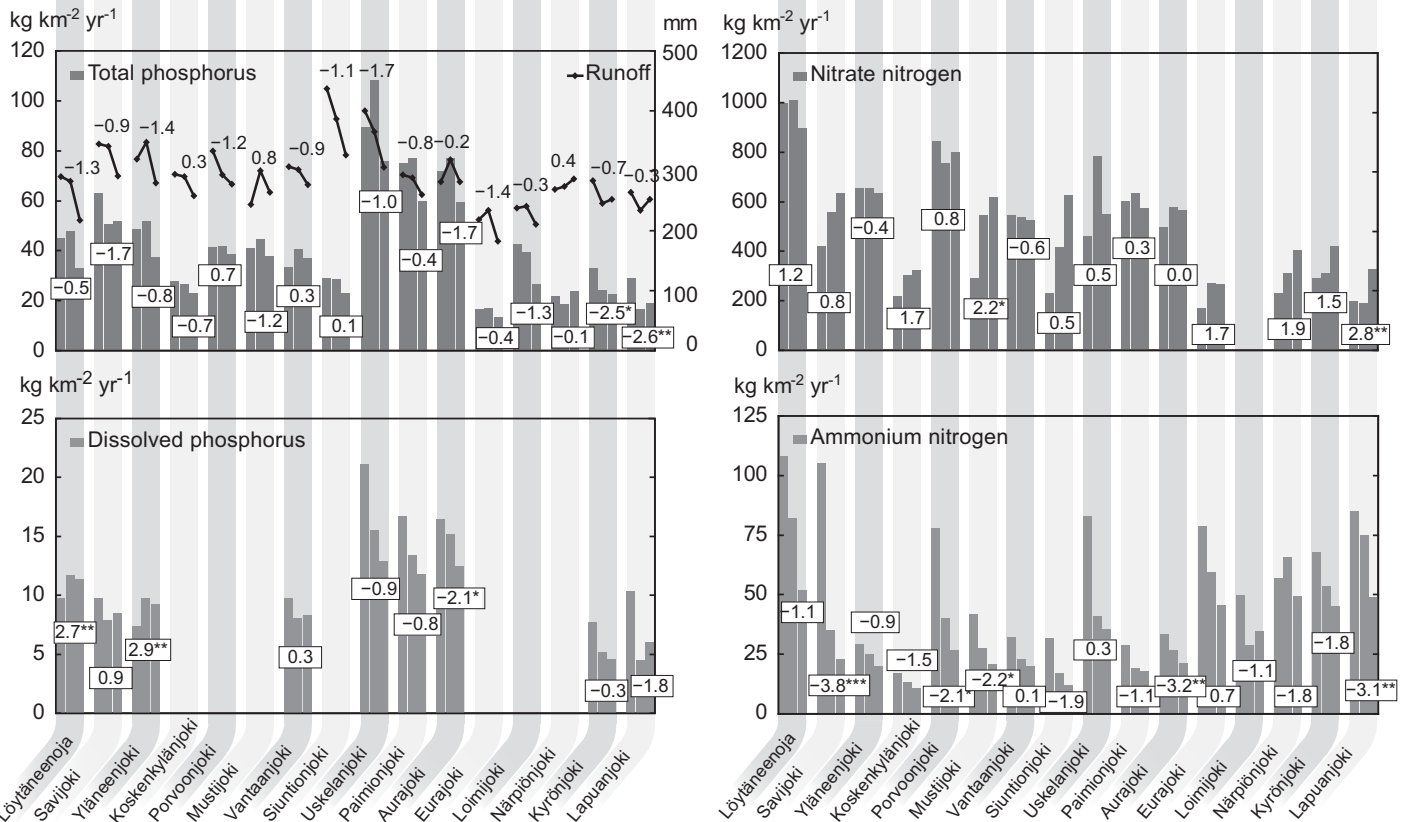

Fig. 5. Mean fluxes of nutrients and total suspended solids (bars) and mean runoff (lines) from agricultural small- to mesoscale catchments by three 5-year periods. Dissolved reactive phosphorus given for the Löytäneenoja, Savijoki and Yläneenjoki catchments and total dissolved phosphorus for other catchments. Partial Mann-Kendall test for trends in the concentrations given in boxes and those in runoff above the lines (years 1990-2004). * $=p<0.05, * *=p<0.01, * * *=p<0.001$.

Concentrations of TSS decreased in each of the eight catchments with adequate data, although the trends were statistically significant only in the three small- and medium-scale ones (Fig. 5). As to TP, a decreasing trend was found in 13 of the 16 study sites, those for the Kyrönjoki and Lapuanjoki being significant. In the case of dissolved $\mathrm{P}$, about half of the sites showed an increasing and about a half a decreasing trend, the Löytäneenoja and Yläneenjoki catchments having a significant increasing and the Aurajoki a significant decreasing trend. Most trends in TN and $\mathrm{NO}_{\mathrm{x}}-\mathrm{N}$ were increasing, although only those in the Lapuanjoki $\left(\mathrm{TN}, \mathrm{NO}_{\mathrm{x}}-\mathrm{N}\right)$ and Mustijoki $\left(\mathrm{NO}_{\mathrm{x}}-\mathrm{N}\right)$ rivers were significant. $\mathrm{NH}_{4}-\mathrm{N}$ was mostly decreasing, five trends being statistically significant.

\section{Trends and levels of nutrients in rivers, lakes and estuaries}

Figure 6 shows the median concentrations of TP, $\mathrm{TN}, \mathrm{NH}_{4}-\mathrm{N}$ and a-chl in the agriculturally loaded 
rivers (no data on a-chl), lakes and estuaries. No clear pattern emerged here, except for $\mathrm{NH}_{4}-\mathrm{N}$ which was mostly decreasing. In two intensively restored lakes (Enäjärvi and Kirkkojärvi), water quality improved. For example, in Kirkkojärvi, the TP median decreased from about $300 \mu \mathrm{g} \mathrm{l}^{-1}$ in 1990-1999 to about $60 \mu \mathrm{g} \mathrm{l}^{-1}$ in $2000-2005$ (Fig. 6). No distinct changes could be found in the medians of the remaining water quality variables (e.g. nutrient fractions).

Table 2 shows the trend analysis for lake water quality. In summer, TP in the surface water layer increased statistically significantly in two out of 19 lakes with adequate data for trend analysis and decreased in the two restored lakes. TN increased significantly in four lakes. Of the nutrient fractions, $\mathrm{NH}_{4}-\mathrm{N}$ showed a decrease in nearly all the lakes, three of the trends being significant.
Turbidity mostly increased and Secchi depth decreased. Wintertime oxygen saturation increased in one lake and decreased in one. In addition TP, $\mathrm{RP}$ and turbidity decreased in one lake (data not shown). The trend analysis for estuarine data did not reveal any general pattern apart from the decreasing $\mathrm{NH}_{4}-\mathrm{N}$ in many estuaries (Table 3). In the Paimionlahti estuary, the significant trends in TP, TN, Secchi depth and turbidity suggested intensifying eutrophication.

In 1998-2005, algal blooms were more common in agriculturally impacted than in non-agricultural lakes. The bloom index in the agricultural lakes was about twice that in the other lakes (Fig. 7). Abundant (class 2) and very abundant (class 3) blooms were also more common in agricultural lakes. The annual bloom index never exceeded 0.5 (Fig. 7), which indicates that severe blooms did
Fig. 6. Median concentrations of chlorophyll $a$, total phosphorus, total nitrogen and ammonium nitrogen by two periods in rivers, lakes and estuaries. For rivers annual data, for lakes and estuaries summer upper water data.
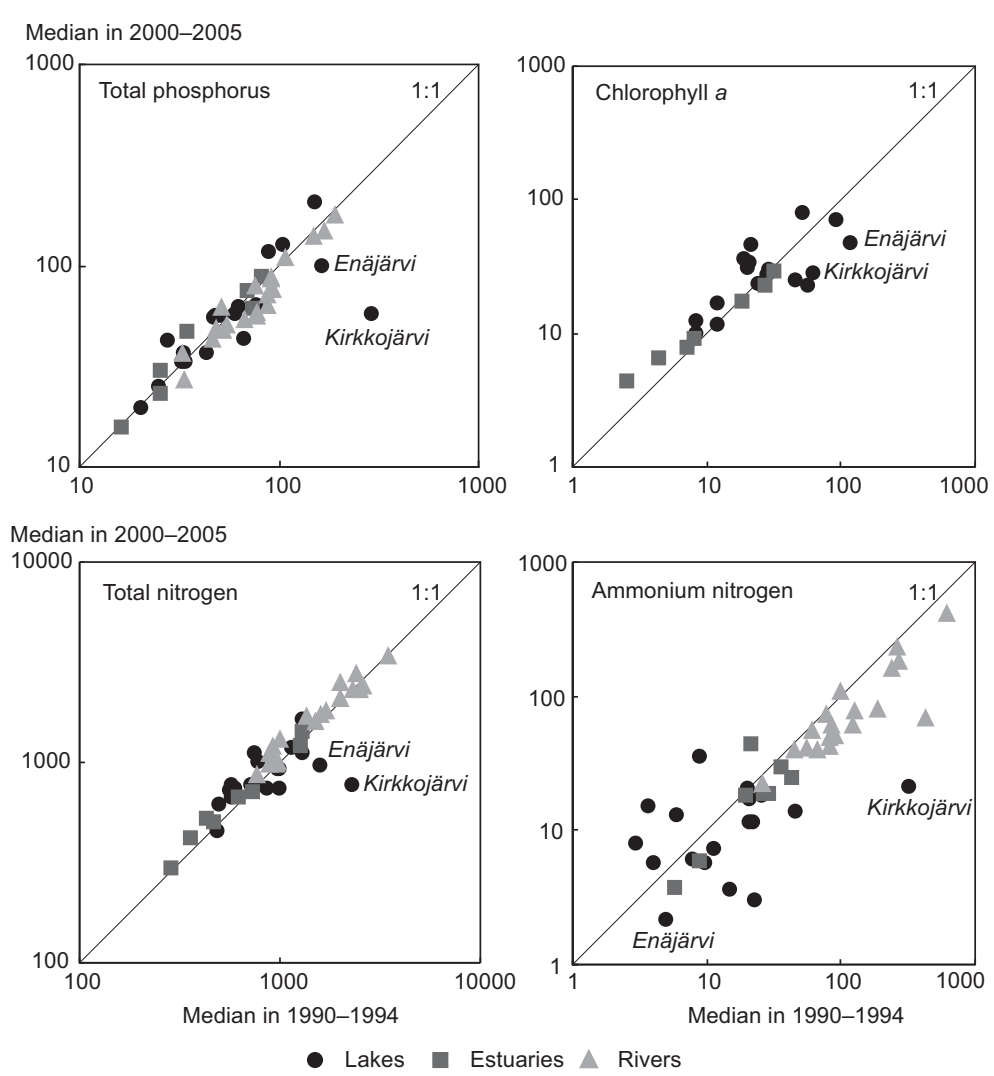


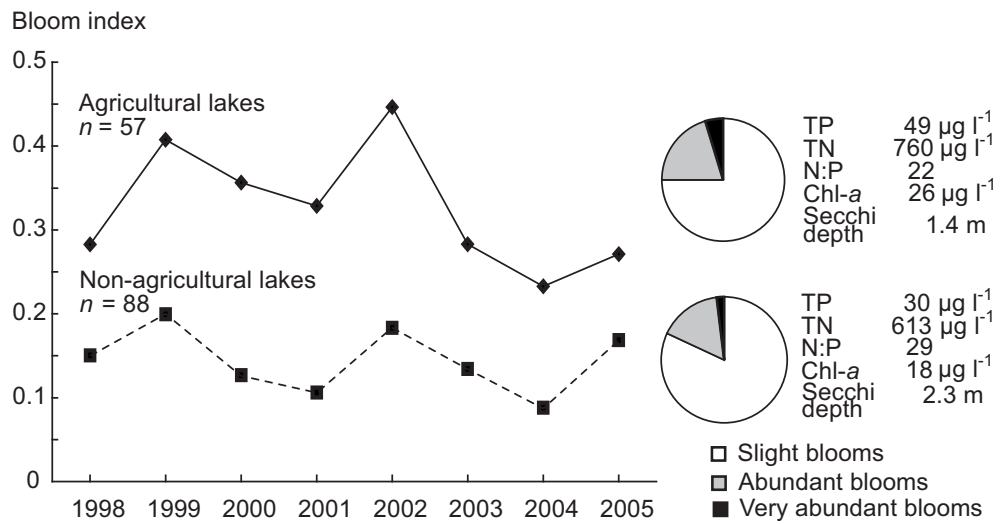

Fig. 7. Algal bloom index, relative amount of slight, abundant and very abundant blooms for all years studied and average water chemistry for agricultural and non-agricultural lakes in 1998-2005. The division between agricultural and nonagricultural lakes is based on expert judgement. not last long. TP, TN and a-chl were higher in the agricultural than in the other lakes. Correspondingly, Secchi depth was lower in the agricultural lakes.

\section{Sediment diatoms}

The diatoms in both bottom (representing background) and top sediments (representing present conditions) were typical of nutrient-rich environments, and the algal assemblages were dominated by only a few species. In 11 of the 15 lakes, the diatom-inferred concentration of TP increased towards the present (Fig. 8). In three lakes, Valkerpyy, Ylisjärvi and Aneriojärvi, the diatom-inferred concentration of TP approximately doubled. In two lakes, Särkijärvi and Mäyhäjärvi, where TP decreased, the present algal communities consisted mainly of small, benthic Fragilaria species and, in Mäyhäjärvi, of Achnanthes minutissima. These diatoms have wide tolerances of $\mathrm{P}$ and are thus poor indicators of the nutrient status of lakes. Their increase may indicate changes in diatom habitats, for example, an increase in macrophyte vegetation at the shores, rather than a change in nutrient concentration.

Generally, the relative abundance of the species typical of productive agricultural lakes was greater in top than in bottom sediments (Fig. 9).
Planktonic taxa, Stephanodiscus hantzschii and $S$. minutulus, were found only in surface sediments and Asterionella formosa and Cyclotella pseudostelligera were also more common in samples representing present conditions. Aulacoseira species, Cyclotella stelligera, selected Fragilaria species and Navicula pupula did not show clear preferences, being abundant both in background and present conditions.

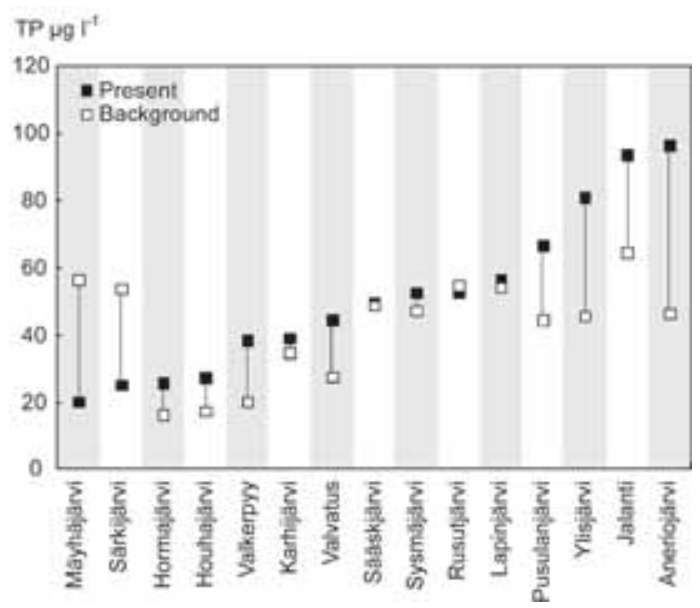

Fig. 8. Diatom-inferred total phosphorus concentrations in top (present) and bottom (background) sediments of the lakes studied. See text for definition of background. 
Fig. 9. Indicator species (see text) for productive, agricultural and disturbed lakes in top (black bars) and bottom samples (open bars), corresponding to present and background conditions. Lakes are classified according to their field percentage in the catchment area, Lake Ylisjärvi having the highest percentage of fields. Aulacoseira* is a composite taxa of Aulacoseira ambigua, A. granulata, A. perglabra, A. subarctica and A. tenella. Stephanodiscus** is a sum of Stephanodiscus hantzschii and S. minutulus/parvus. Fragilaria*** stands for Fragilaria brevistriata, $F$. construes f. construens, F. lapponica and F. pinnata.

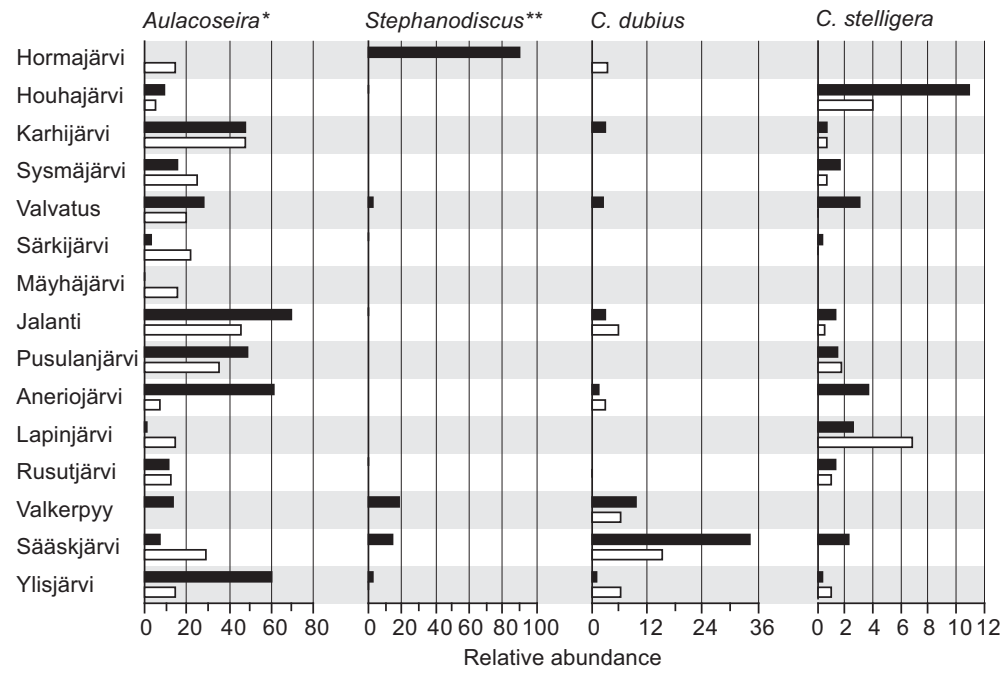

C. pseudostelligera

A. formosa

Fragilaria***

N. pupula

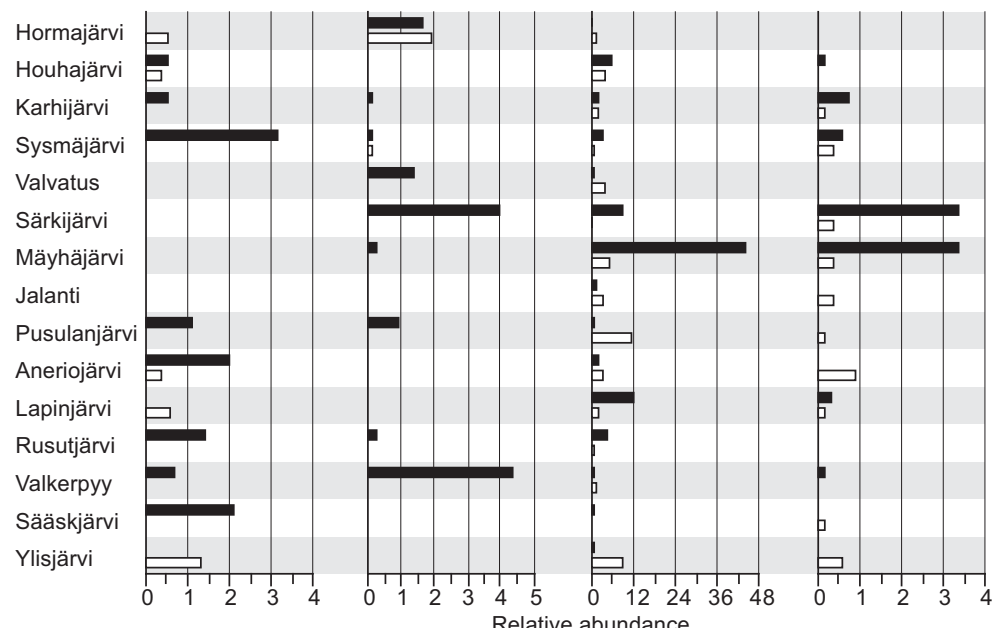

\section{Discussion}

Hydrology causes strong fluctuations in runoff and nutrient losses. However, we found no trends in daily discharge or monthly runoff in 1990-2005. Examination of two 10-year periods demonstrated an increase in the intensity of spring floods in western Finland and a decrease in that of summer floods in south-western Finland in 1995-2004 compared with 1985-1994. Rivers in western Finland are naturally fast flowing and floods develop rapidly. In addition, their catchments are effectively drained and river channels have been heavily modified for hydropower. In 1995-2004 there were some negative NAO indices, which may explain the increased spring floods, as years with a negative NAO index tend to have colder winters and higher spring snow-melt peaks than years with mild winters. The increase in spring floods may affect erosion and PP flux to some extent in western Finland, although the region is not very susceptible to erosion. However, the shifted frequency in summer floods probably does 
not have much effect on nutrient transport or erosion, because summer floods are typically low and vegetation protects the soil surface. Consequently, we could not detect any systematic large-scale changes in hydrology that might have significantly contributed to nutrient losses.

Small and medium-sized catchments showed evidence of decreasing TSS losses and increasing DRP losses. Such a pattern might result from an increased acreage of minimum cultivation, as observed, for instance, in the Yläneenjoki catchment (Pyykkönen et al. 2004). Depending on the soil properties, a change from traditional autumn ploughing to reduced tillage can lower the amount of erosion, but the loss of DRP may increase due to the accumulation of soluble $\mathrm{P}$ in the topsoil (Puustinen et al. 2005, Muukkonen et al. 2007, Turtola et al. 2007, Uusitalo et al. 2007b). In contrast to the observations in small- and mediumscale catchments, dissolved $\mathrm{P}$ decreased in some meso-scale catchments. Fertilizing with $\mathrm{P}$ has decreased in Finland (Ministry of Agriculture and Forestry 2004). However, the response of soil $\mathrm{P}$ status to changes in the soil surface balance of $\mathrm{P}$ is slow (Ekholm et al. 2005) and increase in soil P status levelled out not until in the late 1990s (Uusitalo et al. 2007a). The concentration of DRP in agricultural runoff has been found to be linearly dependent on soil P status (Uusitalo and Jansson 2002). The decrease in $\mathrm{NH}_{4}-\mathrm{N}$ loss observed in many catchments may be due to implementation of the Nitrates Directive, which prohibits the spreading of manure in late autumn and winter. High losses of $\mathrm{NH}_{4}-\mathrm{N}$ in agricultural runoff are often associated with wintertime or autumn surface application of manure (Niinioja 1993, Turtola and Kemppainen 1998), since the temperature is then too low for effective nitrification. However, otherwise the concentrations of $\mathrm{NH}_{4}-\mathrm{N}$ are typically small and thus their contribution to TN losses is often negligible. Evidence of increasing $\mathrm{N}$ losses was observed at several sites. During 1990-2004, the net input of $\mathrm{N}$ to agricultural soil fell from 160 to $120 \mathrm{~kg} \mathrm{ha}^{-1}$, the highest $\mathrm{N}$ surpluses being found in the areas with intensive animal production (Salo et al. 2007). Field-scale modelling shows that losses of $\mathrm{N}$ will decrease if less $\mathrm{N}$ is applied in manure and fertilisers (Granlund et al. 2007, Rankinen et al. 2007). In Denmark, reduced use of $\mathrm{N}$ in agriculture resulted in lower concentrations of $\mathrm{N}$ in runoff (Kronvang et al. 2005), whereas no such change was found in riverine $\mathrm{N}$ concentrations within a few years of a drastic decline in application of $\mathrm{N}$ in the Baltic States (Löfgren et al. 1999). That we found an increase rather than a decrease in $\mathrm{N}$ may be attributed to greater specialisation and to regional intensification of animal husbandry. It would be tempting to link the increase in $\mathrm{N}$ to greater pressure to apply manure in autumn and to a smaller acreage of set-aside. Alternatively, the mineralisation of $\mathrm{N}$ may have been promoted by climate change (Kallio et al. 1997); mineralisation of soil organic matter outside the growing season increases the $\mathrm{N}$ concentrations of runoff (Rankinen et al. 2004).

The fluxes and medians presented here are somewhat uncertain, because the sampling was not flow-proportional (Rekolainen et al. 1991). This is especially true of TP and TSS (Haraldsen and Stålnacke 2006). In addition, incidental losses (Preedy et al. 2001) related to manure spreading have very likely been missed entirely. However, the failure of a clear systematic pattern to emerge from the analysis of 72 agriculturally loaded sites strongly suggests that, thus far, the agri-environmental measures applied in Finland have neither markedly decreased nutrient fluxes nor improved the state of receiving waters.

Sediment diatoms suggest that agricultural lakes that were rich in nutrients before the onset of modern agriculture have become more eutrophic. This is in accordance with the results of other paleolimnological studies on long-term water quality trends in Finnish agricultural lakes (Kauppi et al. 1990, Räsänen et al. 2006). However, in shallow agricultural lakes, sedimentation conditions may lead to sediment reworking that confuses paleolimnological interpretations. Some of these lakes have been partially drained to provide more arable land or to prevent floods. Such man-made changes further complicate estimation of the pristine state of Finnish agricultural lakes. In some estuaries impacted by agriculture, the first changes in species composition indicating eutrophy took place 


\section{AGRICULTURAL AND FOOD SCIENCE}

Vol. 16 (2007): 282-300

in the 1940s, coinciding with the intensification of Finnish agriculture. No simultaneous increase in diatom-inferred water TN concentrations was observed (Weckström 2006). The status of rural estuaries was lowest in the 1980s. Today, the mean of diatom-inferred total dissolved nitrogen (TDN) in rural estuaries departs by up to $20 \%$ from its reference conditions in the late $1880 \mathrm{~s}$, which is less than observed in urban estuaries (Weckström 2005).

Algal blooms were more common in agriculturally impacted than in other lakes. This finding confirms the earlier observation that agricultural lakes are the most eutrophic lake type in Finland (Mitikka and Ekholm 2003). It is difficult to conclude decisively whether the recurrent blooms are only due to anthropogenic nutrient loading or partially also due to the location of the lakes in fertile catchments, especially as algal blooms are a natural phenomenon occasionally observed in all waters (McGowan and Britton 1999).

\section{Conclusions}

No consistent and systematic decreases in losses of nutrients (except of $\mathrm{NH}_{4}-\mathrm{N}$ ) from agricultural catchments were found when the Agri-Environmental Program period (1995-2004) was compared with the reference period (1990-1994). Consequently, no clear improvement in the state of agriculturally impacted rivers, lakes or estuaries was detected. Hydrological fluctuations do not appear to have eclipsed the effects of the measures taken, since there was no systematic pattern in hydrology in the period studied. The lack of explicit results may partly be due to the increased area of agricultural land and to the intensification of agricultural production in EU Finland. The conditions set for agri-environmental support for the third period (2007-2013) will be stricter in some respects, e.g. the application of $\mathrm{P}$ in fertilizers. Our study supports this new rigorous requirement. Reducing $\mathrm{N}$ fluxes in the changing climate calls for special attention. The agri-environmental measures carried out in Finland so far have not effectively taken into account the huge spatial diversity in agricultural loading. The programme could probably achieve better results if the measures focused specifically on the areas and actions that contribute most to the current loading.

Acknowledgements. We thank Tommi Kauppila for performing the diatom-inferred TP reconstructions, Heidi Vuoristo for defining the loading of algal bloom network lakes, Timo Hänninen for finding the nearest water chemistry sampling sites to algal bloom observation sites, Jonatan Hilden for finalising the figures and Gillian Häkli for revising the English. Juha Grönroos, Kirsti Krogerus and two anonymous referees made constructive comments on the manuscript.

\section{References}

Battarbee, R., Jones, V., Flower, R., Cameron, N. \& Bennion, H. 2001. Diatoms. In: Smol, J.P., Birks, H.J.B. \& Last, W.M. (eds.). Tracking environmental change using lake sediments, Volume 3: Terrestrial, algal, and siliceous indicators. Dortrecht: Kluwer Academic Publishers. p. 155-202.

Bechmann, M. \& Stålnacke, P. 2005. Effect of policy-induced measures on suspended sediments and total phosphorus concentrations from three Norwegian agricultural catchments. Science of the Total Environment 344: 129-142.

Brockwell, P.J. \& Davis, R.A. 2002. Introduction to Time Series and Forecasting. Springer Verlag. 421 p.

Chow, V.T., Maidment, D.R. \& Mays, L.W. 1988. Applied Hydrology. McGraw-Hill, Inc. 572 p.

Cumming, B.F., Smol, J.P., Kingston, J.C., Charles, D.F., Birks, H.J.B., Camburn, K.E., Dixit, S.S., Uutala, A.J. \& Selle, A.R 1992. How much acidification has occurred in Adirondack region lakes (New-York, USA) since preindustrial times. Canadian Journal of Fisheries and Aquatic Sciences 49: 128-141.

Drebs, A., Nordlund, A., Carlsson, P., Helminen, J. \& Rissanen, P. 2002. Climatological statistics of Finland 1971-2000. Climatological statistics of Finland, Finnish Meteorological Institute. $99 \mathrm{p}$.

EC. 2000. Directive 2000/60/EC of the European Parliament and of the Council of 23 October 2000 establishing a framework for Community action in the field of water policy. Official Journal L 327: 1-73.

EEC. 1991. Council Directive 91/676/EEC of 12 December 1991 concerning the protection of wa-ters against pollution caused by nitrates from agricultural sources. Official Journal L 375: 1-8.

EEC. 1992. Council Regulation (EEC) No 2078/92 of 30 June 1992 on agricultural production methods compatible with the requirements of the protection of the environment and the maintenance of the countryside. Official Journal of the European Communities No L215: 85-90.

Ekholm, P. \& Mitikka, S. 2006. Agricultural lakes in Finland Current water quality and trends. Environmental Monitoring and Assessment 116: 111-135.

Ekholm, P., Turtola, E., Gronroos, J., Seuri, P. \& Ylivainio, K. 2005. Phosphorus loss from different farming systems estimated from soil surface phosphorus balance. Agriculture Ecosystems \& Environment 110: 266-278. 


\section{AGRICULTURAL AND FOOD SCIENCE}

\section{Ekholm, P. et al. Nutrient losses and the state of surface waters}

Granlund, K., Bärlund, I., Salo, T., Esala, M. \& Posch, M. 2007. The effect of decreasing $N$ fertilisation on agricultural $\mathrm{N}$ leaching - A model study. Agricultural and Food Science 16: 376-386.

Granlund, K., Räike, A., Ekholm, P., Rankinen, K. \& Rekolainen, S. 2005. Assessment of water protection targets for agricultural nutrient loading in Finland. Journal of Hydrology 304: 251-260.

Haraldsen, T.K. \& Stålnacke, P. 2006. Methods for water quality sampling and load estimation in monitoring of Norwegian agricultural catchments. Nordic Hydrology 37 : 81-92.

Hyvärinen, V. 2003. Trends and characteristics of hydrological time series in Finland. Nordic Hydrology 34: 71-90.

Kalayci, S. \& Kahya, E. 2006. Assessment of streamflow variability modes in Turkey: 1964-1994. Journal of Hydrology 324: 163-177.

Kallio, K., Rekolainen, S., Ekholm, P., Granlund, K., Laine, Y., Johnsson, H. \& Hoffman, M. 1997. Impact of climatic change on agricultural nutrient losses in Finland. Boreal Environment Research 2: 33-52.

Kauppi, L., Knuuttila, S., Sandman, K., Eskonen, K., Luokkanen, S. \& Liehu, A. 1990. Role of landuse in the occurrence of blue-green algal blooms. Verhandlungen der internationationale Vereinigung für theoretische und angewandte Limnologie 24: 671-676.

Kauppila, P., Meeuwig, J.J. \& Pitkänen, H. 2003. Predicting oxygen in small estuaries of the Baltic Sea: a comparative approach. Estuarine Coastal and Shelf Science 57: 1115-1126.

Kauppila, T., Moisio, T. \& Salonen, V.P. 2002. A diatom-based inference model for autumn epilimnetic total phosphorus concentration and its application to a presently eutrophic boreal lake. Journal of Paleolimnology 27: 261-273.

Kronvang, B., Jeppesen, E., Conley, D.J., Søndergaard, M., Larsen, S.E., Ovesen, N.B. \& Carstensen, J. 2005. Nutrient pressures and ecological responses to nutrient loading reductions in Danish streams, lakes and coastal waters. Journal of Hydrology 304: 274-288.

Kyllmar, K., Carlsson, C., Gustafson, A., Ulen, B. \& Johnsson, H. 2006. Nutrient discharge from small agricultural catchments in Sweden - characterisation and trends. Agriculture, Ecosystems \& Environment 115: 15-26.

Lehtonen, H. \& Pyykkönen, P. 2005. Maatalouden rakennekehitysnäkymät vuoteen 2013, Abstract: Structural change in Finnish Agriculture up to 2013. MTT:n selvityksiä 100, Pellervon taloudellisen tutkimuslaitoksen työpapereita 78. $40 \mathrm{p}$.

Lepistö, L., Rissanen, J. \& Kotilainen, P. 1998. Intensive monitoring of algal blooms in Finnish inland and coastal waters. Ympäristö ja terveys -lehti 7: 30-36.

Libiseller, C. \& Grimvall, A. 2002. Performance of partial MannKendall tests for trend detection in the presence of covariates. Environmetrics 13: 71-84.

Löfgren, S., Gustafson, A., Steineck, S. \& Stålnacke, P. 1999. Agricultural development and nutrient flows in the Baltic states and Sweden after 1988. Ambio 28: 320-327.

Mattila, P., Grönroos, J., Rankinen, K., Laitinen, P., Karhu, E. \& Granlund, K. 2007. Ympäristötuen mukaiset viljelytoimenpiteet ja niiden vaikutukset vesistökuormitukseen vuosina 2003-2005. Suomen ympäristö. (in press.)

McGowan, S. \& Britton, G. 1999. Ancient blue-green blooms. Limnology and Oceanography 44: 436-439.

Meeuwig, J.J., Kauppila, P. \& Pitkanen, H. 2000. Predicting coastal eutrophication in the Baltic: a limnological approach. Canadian Journal of Fisheries and Aquatic Sciences 57: 844-855.

Meriläinen, J., Huttunen, P., Pirttiala, K. 1983. The effect of land use on the diatom communites in lakes. Hydrobiologia 86: 99-103.
Miettinen, J.O. 2003. A diatom-total phosphorus transfer function for freshwater lakes in southeastern Finland, including cross-validation with independent test lakes. Boreal Environment Research 8: 215-228.

Miettinen, J.O., Kukkonen, M. \& Simola, H. 2005. Hindcasting baseline values for water colour and total phosphorus concentration in lakes using sedimentary diatoms - implications for lake typology in Finland. Boreal Environment Research 10: 31-43.

Ministry of Agriculture and Forestry. 2004. Horisontaalisen maaseudun kehittämisohjelman väliarviointi. MannerSuomi, Summary: Mid-term evaluation of the Horizontal Rural Development Programme. MMM:n julkaisuja 1/2004. $273 \mathrm{p}$.

Mitikka, S. \& Ekholm, P. 2003. Lakes in the Finnish Eurowaternet: status and trends. Science of the Total Environment 310: $37-45$.

Mitikka, S., Britschgi, R., Granlund, K., Grönroos, J., Kauppila, P., Mäkinen, R., Niemi, J., Pyykkönen, S., Raateland, A. \& Silvo, K. 2005. Report on the implementation of the Nitrates Directive in Finland 2004. The Finnish Environment 741. $92 \mathrm{p}$.

Murphy, J. \& Riley, J.P. 1962. A modified single solution method for the determination of phosphate in natural waters. Analytica Chimica Acta 27: 31-36.

Muukkonen, P., Hartikainen, H., Lahti, K., Särkelä, A., Puustinen, M. \& Alakukku, L. 2007. Influence of no-tillage on the distribution and lability of phosphorus in Finnish clay soils. Agriculture, Ecosystems \& Environment 120: 299-306.

Myrberg, K., Leppäranta, M. \& Kuosa, H. 2006. Itämeren fysiikka, tila ja tulevaisuus. Yliopistopaino, Helsinki University Press, Palmenia. $201 \mathrm{p}$.

Niemi, J. 2006. Ympäristön seuranta Suomessa 2006-2008. Suomen ympäristö 24. $151 \mathrm{p}$.

Niemi, J. \& Ahlstedt, J. (eds.). 2005. Finnish agriculture and rural industries 2005 - Ten years in the European Union. MTT Economic Research, Agrifood Research Finland. 94 p.

Niinioja, R. 1993. Lietelannan levitys ja ravinteiden huuhtoutuminen, Summary: Leaching of nutrients from application of slurry. Vesi- ja ympäristöhallinnon julkaisuja -sarja A 150. $90 \mathrm{p}$.

Preedy, N., McTiernan, K., Matthews, R., Heathwaite, L. \& Haygarth, P. 2001. Rapid incidental phosphorus transfers from grassland. Journal of Environmental Quality 30: 2105-2112.

Puustinen, M., Koskiaho, J. \& Peltonen, K. 2005. Influence of cultivation methods on suspended solids and phosphorus concentrations in surface runoff on clayey sloped fields in boreal climate. Agriculture, Ecosystems \& Environment 105: 565-579.

Puustinen, M., Tattari, S., Koskiaho, J. \& Linjama, J. 2007. Influence of seasonal and annual hydrological variations on erosion and phosphorus transport from arable areas in Finland. Soil and Tillage Research 93: 44-55.

Pyykkönen, S., Grönroos, J., Rankinen, K., Laitinen, P., Karhu, E. \& Granlund, K. 2004. Ympäristötuen mukaiset viljelytoimenpiteet ja niiden vaikutukset vesistökuormitukseen vuosina 2000-2002, Summary: Cultivation measures in 2000-2003 and their effects to the nutrient runoff to the waters in the farms committed to the Agri-Environmental Programme. The Finnish Environment 711. 119 p.

Räike, A., Pietiläinen, O.P., Rekolainen, S., Kauppila, P., Pitkänen, H., Niemi, J., Raateland, A. \& Vuorenmaa, J. 2003. Trends of phosphorus, nitrogen and chlorophyll a concentrations in Finnish rivers and lakes in 1975-2000. Science of the Total Environment 310: 47-59.

Rankinen, K., Granlund, K. \& Bärlund, I. 2004. Modelling of seasonal effects of soil processes on $\mathrm{N}$ leaching in northern latitudes. Nordic Hydrology 35: 347-357. 


\section{AGRICULTURAL AND FOOD SCIENCE}

Vol. 16 (2007): 282-300

Rankinen, K., Salo, T., Granlund, K. and Rita, H. 2007. Simulated nitrogen leaching, nitrogen mass field balances and their correlation on four farms in south-western Finland during the period 2000-2005. Agricultural and Food Science 16: 387-406.

Räsänen, J., Kauppila, T. \& Salonen, V.P. 2006. Sedimentbased investigation of naturally or historically eutrophic lakes - implications for lake management. Journal of Environmental Management 79: 253-265.

Rekolainen, S., Posch, M., Kämäri, J. \& Ekholm, P. 1991. Evaluation of the accuracy and precision of annual phosphorus load estimates from 2 agricultural basins in Finland. Journal of Hydrology 128: 237-255.

Salo, T., Lemola, R. \& Esala, M. 2007. National and regional net $\mathrm{N}$ balances in Finland in 1990-2004. Agricultural and Food Science 16: 366-376.

Smol, J.P. 2002. Pollution of lakes and rivers: a paleoenvironmental perspective. Arnold Publishers, London. 280 p.

Stålnacke, P., Grimvall, A., Libiseller, C., Laznik, A. \& Kokorite, I. 2003. Trends in nutrient concentrations in Latvian rivers and the response to the dramatic change in agriculture. Journal of Hydrology 283: 184-205.

Stålnacke, P., Vandsemb, S.M., Vassiljev, A., Grimvall, A. \& Jolankal, G. 2004. Changes in nutrient levels in some Eastern European rivers in response to large-scale changes in agriculture. Water Science and Technology 49: 29-36.

Stroemer, E. \& Smol, J.P. (eds.). 2000. The Diatoms: Applications for the Environment and Earth Sciences. Cambridge: Cambridge University Press. $469 \mathrm{p}$.

Tattari, S. \& Linjama, J. 2004. Vesistöalueen kuormituksen arviointi. Vesitalous 3/2004: 26-30.

Ter Braak, C. \& van Dam, H. 1989. Inferring $\mathrm{pH}$ from diatoms: a comparison of old and new calibration methods. Hydrobiologia 269/270: 485-502.

Tuomenvirta, H. 2004. Reliable estimation of climatic variations in Finland. Finnish Meteorological Institute Contributions, Finnish Meteorological Institute. 158 p.

Turtola, E. \& Kemppainen, E. 1998. Nitrogen and phosphorus losses in surface runoff and drainage water after application of slurry and mineral fertilizer to perennial grass ley. Agricultural and Food Science in Finland 7: 569-581.

Turtola, E., Alakukku, L., Uusitalo, R. \& Kaseva, A. 2007. Surface runoff, subsurface drainflow and soil erosion as affected by tillage in a clayey Finnish soil. Agricultural and Food Science in Finland 16: 332-351.

Ulén, B. \& Fölster, J. 2007. Recent trends in nutrient concentrations in Swedish agricultural rivers. Science of the Total Environment 373: 473-487.
Uusi-Kämppä, J. 2002. Nitrogen and phosphorus losses from a feedlot for suckler cows. Agricultural and Food Science in Finland 11: 355-369.

Uusi-Kämppä, J., Jauhiainen, L. \& Huuskonen, A. 2007. Phosphorus and nitrogen losses to surface waters from a forested feedlot for bulls in Finland. Soil Use and Management 23 (Suppl. 1): 82-91.

Uusitalo, R. \& Jansson, H. 2002. Dissolved reactive phosphorus in runoff assessed by soil extraction with an acetate buffer. Agricultural and Food Science in Finland 11: 343-353.

Uusitalo, R., Turtola, E., Grönroos, J., Kivistö, J., Mäntylahti, V., Turtola, A., Lemola, R. \& Salo, T. 2007a. Finnish trends in phosphorus balances and soil test phosphorus. Agricultural and Food Science in Finland 16: 301-316.

Uusitalo, R., Turtola, E. \& Lemola, R. 2007b. Phosphorus losses from a subdrained clayey soil as affected by cultivation practices. Agricultural and Food Science in Finland 16: 352-365.

Vagstad, N., Stålnacke, P., Andersen, H.E., Deelstra, J., Jansons, V., Kyllmar, K., Loigu, E., Rekolainen, S. \& Tumas, R. 2004. Regional variations in diffuse nitrogen losses from agriculture in the Nordic and Baltic regions. Hydrology and Earth System Sciences 8: 651-662.

Valpasvuo-Jaatinen, P., Rekolainen, S. \& Latostenmaa, H. 1997. Finnish agriculture and its sustainability: Environmental impacts. Ambio 26: 448-455.

Vuorenmaa, J., Rekolainen, S., Lepistö, A., Kenttämies, K. \& Kauppila, P. 2002. Losses of nitrogen and phosphorus from agricultural and forest areas in Finland during the 1980s and 1990s. Environmental Monitoring and Assessment 76: 213-248.

Weckström, K. 2005. Recent eutrophication of coastal waters in southern Finland - A palaeolimnological assessment. Division of Aquatic Sciences, University of Helsinki.

Weckström, K. 2006. Assessing recent eutrophication in coastal waters of the Gulf of Finland (Baltic Sea) using subfossil diatoms. Journal of Paleolimnology 35: 571-592.

Wivstad, M., Dahlin, A.S. \& Grant, C. 2005. Perspectives on nutrient management in arable farming systems. Soil Use and Management 21: 113-121.

Yoo, J. \& D'Odorico, P. 2002. Trends and fluctuations in the dates of ice break up of lakes and rivers in Northern Europe: the effect of the North Atlantic Oscillation. Journal of Hydrology 268: 100-112. 
Ekholm, P. et al. Nutrient losses and the state of surface waters

\title{
SELOSTUS
}

\section{EU:n ympäristöohjelman vaikutus vesien ravinnekuormaan ja tilaan}

\author{
Petri Ekholm, Kirsti Granlund, Pirkko Kauppila, Sari Mitikka, Jorma Niemi, Katri Rankinen, \\ Antti Räike ja Johanna Räsänen \\ Suomen ympäristökeskus
}

\begin{abstract}
Maataloudestamme peräisin olevan ravinnekuorman vähentäminen aloitettiin laaja-alaisesti vuonna 1995, jolloin Suomessa käynnistettiin EU:n maatalouden ympäristöohjelma. Tässä tutkimuksessa selvitettiin valtakunnallisten seuranta-aineistojen perusteella, onko maatalouden ravinnekuorma ja maatalouden kuormittamien jokien, järvien ja rannikkovesien tila muuttunut verrattaessa kautta 1990-1994 kausiin 1995-1999 ja 2000-2004.

Yksiselitteistä kuormituksen vähentymistä ei havaittu. Eräillä alueilla ammoniumtypen ja kiintoaineen kulkeuma vähentyi, mutta vastaavasti liuenneen fosforin kuorma nousi. Myös vastaanottavien vesien tila
\end{abstract}

pysyi pääosin ennallaan. Jos maatalouden vesiensuojelutoimet olisi kohdennettu kaikkein kuormittavimmille alueille, niiden teho olisi ehkä ollut parempi. Toisaalta maatalousmaan suuret ravinnevarat hidastavat kuormituksen vähenemistä. Vuodesta toiseen voimakkaasti vaihtelevat hydrologiset olot vaikeuttavat maatalouden toimien vaikutusten havaitsemista seuranta-aineistoissa. Muutokset hydrologiassa eivät kuitenkaan selittäneet vähäistä muutosta maataloudesta peräisin olevassa kuormassa. Maataloustuotannon keskittyminen ja erikoistuminen samoin kuin ilmaston muutos ovat voineet vähentää ympäristötoimien vaikutusta. 